\title{
INDIVIDUAL'S RESISTANCE TO SOCIAL CRISES IS ACQUIRED IN CHILDHOOD
}

\begin{abstract}
Objective: the development of person's resistance to crises. The aim of the study is to reveal the importance of childhood experience to the person, by acquiring resistance to crises; the need of pedagogical help in overcoming adaptation difficulties of the first-year pupil at school. The analysis of pedagogical, psychological, philosophical literature; the analysis of empirical research and statistic data; as well as the method of observation were used in the current study. Though 60 percent of preparation possibilities for life are realised until the beginning of the first grade, the analysis of various authors' research, quantitative analysis and observation of firstyear pupils in the schools of Vilnius, allow us to conclude that the main reason for a difficult adaptation of first-year pupils is the prevailing belief, that individuals 'preparation for life begins at school. Educational system is based on rendering of the knowledge rather than the development of thinking ability and universal recognition of the environment. Inactivated brain during infancy and early childhood reduces the possibility of mastering information provided at school, and using it in life. Family is the basis, which provides the feeling of safety, which instils real values, which creates the conditions of developing resistance to social changes, and various adaptational skills, which are particularly necessary in the contemporary changing society. Extra attention should be paid to the education of parents and preparation for responsible parenthood.

Keywords: adaptation; character features of a balanced child; childhood, dependent children; egoistic children; family surroundings, incommunicative children; problems of children; responsible children; sensitive periods of the development of person's crises resistance instruments
\end{abstract}

\section{INTRODUCTION}

Childhood is both the product of human development and educational culture in society. The aim of this paper is to establish, how the child is helped through this period (from birth to the first year at school) to belong in the society: in micro-macro environment, which helps him/her to become a member of a social group, and society; what adaptation problems arise during childhood.

Various experiences during childhood determine the development of a balanced personality. Only such a person can successfully adapt to new true-life situations, quickly overcome critical situations. Bringing up a child in a family plays a significant role during this age, moreover it determines the type of child's character: the self-help of affection, self-sufficiency, self-confidence, and obeying the rules.

The basic character types of the developing person determine, what strategies and methods will be used in the nearest future, while being in critical situations or crisis-stricken. In relation to the closest environment (family, peers) it is important to mention the importance of modern technologies, such as the television and computers. It is observed that different experiences, gained at childhood, become an instrument of resistance to crises in the future (Burvyte, 2004; Kvieskienè, 2005; Miškinis, 2003; Gliokler, 2003; Pfiffner, 2001; Grigas, 1995). 


\section{THE AIM OF THE STUDY}

To reveal the importance of childhood experience to the person, by acquiring the resistance to crises; the need of pedagogical help in overcoming adaptation difficulties of the first-year pupil at school.

Objective: the development of person's resistance to crises.

\section{MATERIALS AND METHODS}

People live in societies, which both in the past and nowadays (and this will regularly happen in the future) have survived through various crises, which make it necessary to acquire adaptational instruments, helping to successfully adjust to social changes. A person should be able to solve personal crises by positive behaviour, creating inner harmony and managing to satisfy his/her needs.

Already in 1961 J. H. van den Berg states, that all psychological problems are a product of socio-historical cultural changes. He believes that there is no "human nature", but merely the shifting temper of a person, in accordance with social changes.

By this article, we want to point out the importance of development of a harmonious personality in the preschool and primary school attending period; to the conditions that are necessary in the upbringing of successful child; if there is a need, to providing help to the family in choosing the right direction of upbringing, because this determines the successful realization of adaptational possibilities in the sensitive periods and sets the conditions to develop the preparation to overcome personal crises successfully/unsuccessfully and to adapt to the social crises positively. The subjects determining the resistance of person's development to crises during the sensitive periods in the early stage of person's development, will be analysed further.

\section{Sensitive periods of the development of person's crises resistance instruments}

There is a set of all genes in the first cell of foetus, which contains information about the forthcoming body of the person, his/her competence and health. Their materialization depends on the environment. Since we cannot change our nature, we can change the environment, which constructs the conditions for the development of personality; we can adjust, depending on the personal potential. The importance of the environment is extremely significant during the sensitive periods of personality's self-help: from birth to early school age. During this period the self-helping personality acquires adaptational instruments, the quality of which depends on the diversity of experience.

According to the research of T. Helbrüge and J. Herman fon Wimpfen (1998), the individual uses or activates only 10 percent of the brain mass. The activation happens through experience, by contacting the environment. If an infant or a child is isolated, or his/her chance to come in contact with the environment is limited, his/her opportunities of readjustment are smaller. On the other hand, the more chances an infant or a child gets in recognizing the environment, the more versatile he/she becomes (see Figure 1).

The unused potentialities of readjustment during infancy and early childhood load up and reduce the possibility to adapt in other stages of development. During the preschool age, the child has an opportunity to absorb more than 50 percent of experience, which is necessary for qualitative and successful existence. D. T. Dodge, L. J. Colker, and D. G. Koralek (Koralek, Colker \& Dodge, 2002) state that child's brain gyri experiences positive effect, when children are satisfied, they feel safe and have steady bonds with the family. The sensitive periods (sentimental phases) also exist, when the brain is most receptive to save a particular experience. In preschool years, children are most susceptible to the control of emotions, formation of relations with other children, and language-learning skills; they only need the right impact. 


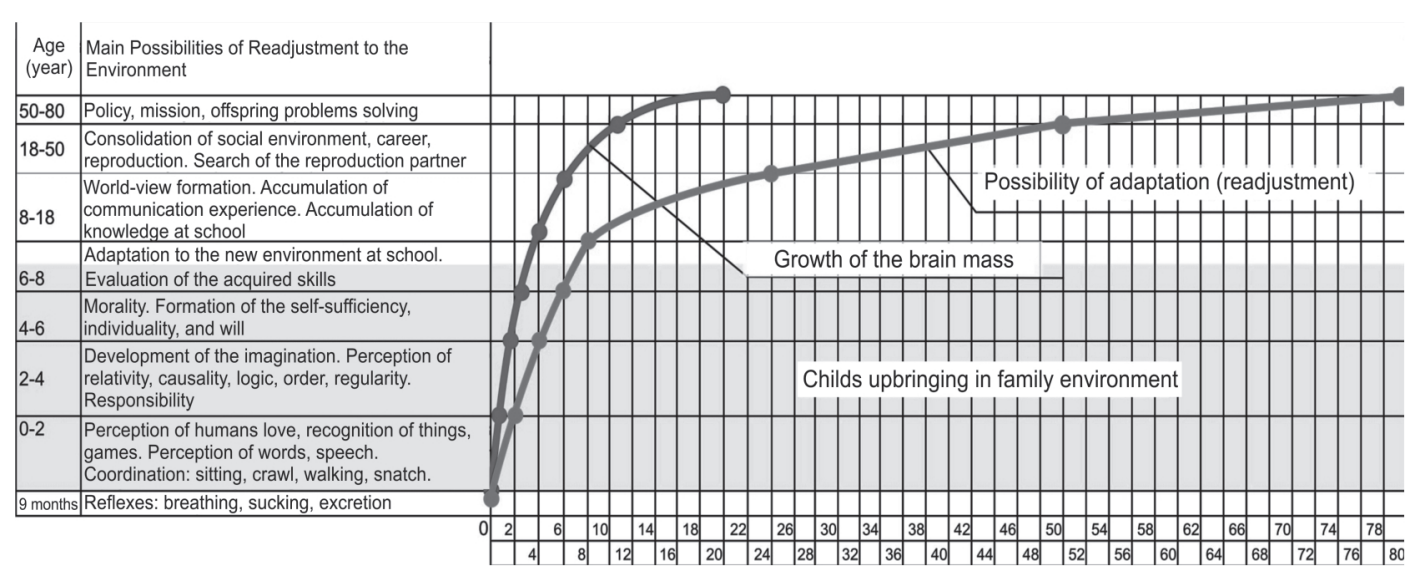

\section{Figure 1. Diagram on individual's adaptation (readjustment) possibility reliance on age and brain activation (Burvytè, 2011 (adapted according to T. Helbrüge and J. Herman fon Wimpfen (cf. 1998, 24)))}

It can be stated, that the results of brain analysis proved the truth claimed by such scholars as A. Maslow (1999), E. Erikson (2004), K. Horney (2004), J. Bowlby (1969), D. Baumrind (1971), J. Piaget (1954), Л.С. Выготский (2005), and F. Riemann (2004). After analysing the adaptation of first-year pupils at school and summing up the insights of different authors, it can be claimed, that the stages of person's development, presented by these scholars, and studied in every aspect, are the realization of adaptational possibilities: the result of brain growth and environmental influence.

The child, subject to various qualitative and age-adequate experiences, incarnates adaptational possibilities during the preschool period, by satisfying his/her needs and forming a harmonious individuality.

In Figure 1 we can see that the fastest development of brain mass happens during the preschool period; moreover, activating it on purpose, particular experiences are required. For example, if a child does not learn to speak until the age of 4 , it can be extremely hard or even impossible to do it later.

Summing up these insights, it can be stated that the quality of child's possibilities for the realization of adaptation during the preschool period makes an impact on the expression of his/her adaptation at later stages of development. The interferences of child's self-help (they can be understood as family's incapability to create conditions for successful self-help of the child) during the sensitive periods, and the possible outcome, i.e., the unacceptable behaviour of the acquired character features, by expressing aggression, in the intimate partnership and the positive and negative range development of character features.

In our society this phenomenon is not appreciated enough: the acquisition of children's adaptational instruments during the early stage of development, and the acquired behaviour habits in trying to satisfy the needs, predicts the future. Associating this with the ability to overcome personal and social crises in the future, the links to preschool period self-help obstructions show up, which are experienced in a family with adaptation difficulties, which commonly develop in school, and at later stages of person's development, while adjusting to the changing conditions of the environment (Eisenberg, 1999). 
Child's preschool experiences, his/her versatile maturity influence the primary fortune of adaptation to the new environment. The main role goes to the family in the process of children's development. Successful child's preparation, adaptation to the changes, and versatile maturity in school depends on the experiences within the family.

The research of scientific literature reveals, that before going to school, a child must have diverse experience of understanding the world (he/she has to face various experiences), which has an influence on a successful adaptation to different changes of the environment.

Both in the preschool period and the first-year period, family's influence on the child is extremely important. According to the investigation of T. Helbrüge and J. Herman fon Wimpfen (1998), the smaller the child, the more flexible he/she is to environmental changes; this might require bigger effort at further stages. The preparation for adaptation to new situations (especially during the first year in school) is based on the child's experience in the preschool period.

According to F. Riemann (2004), children's characters are very different. The research of psychoanalyst K. Horney (2004) proves that the formation of person's character features is based on socio-cultural aspects, rather than biological ones. The individual acquires these features through various experiences. Such character features, as breakaway or avoidance of close relationships, the inability to feel, dependence, constant attention seeking or scrupulous keeping of the rules, constitute the reflection of our culture.

As R. May (2010) states, the strangeness of a person who avoids close relationships is the defence against hostility, which originates in infancy, namely, the lack of love, distrust; because of that the person constantly fears real love, for it "raises danger to his/her existence". Parents themselves are powerless and unconscious products of culture of their epoch with dominating character features, which were determined by the natural environment of information technologyl age. Such states as the avoidance of close relationships, dependence, keeping the rules scrupulously or constant attention seeking, are fixed in the structure of parents' personalities and form an adequate way of life, which is transmitted to their children.

After an overview of the importance of the family to the formation of children's character features during the sensitive period, as the preparation for adjustment to various environmental changes, the theme of child's adaptation to the environment will be introduced: school, friends, the mass media, etc., their expectations to the child, in response to which he/she must readjust.

Research methods and organization. In order to estimate the preparation of preschool children to adapt successfully to the new environment (during the first year at school), the method of observation was applied. The attention was paid to the expression of children's adaptation to the daily class environment; as well as to the readjustment of manners, types of behaviour. The analysis of scientific literature revealed that the phenomenon of adaptation in the first grade is not evaluated properly, because the way children adapt in the beginning of the school, forecasts the future, answers the question of whether they will use adaptational instruments in the future. The earlier they acquire the instruments, the tighter they are in personality's structure.

The argumentation of observation method: to distinguish particular children and to fix concrete problems of their daily behaviour in the first grade, by using the method of observation.

The data is gathered by the method of observation. In this way the children's adaptation process is being defined, which is happening in natural conditions, and is seen realistically. One of the aims is to investigate the behaviour of the first-year pupil thoroughly, which raises adaptational difficulties in the community of the class (Kardelis, 1997). With the consent of 
teachers and parents, the observation was implemented during lessons and breaks, in the morning, when parents brought children to school, after lessons, when they were taken home. The behaviour of children was observed during various lessons, both while learning, and playing during breaks. 168 first-year pupils participated in the investigation. The results were recorded and noted. The observation lasted for 3 months, from September till November, each working day, from $8.30 \mathrm{am}$. till $2.30 \mathrm{pm}$. In total 390 hours were devoted to observation. In accordance with the daily recorded behaviour problems during lessons and break times (which the child solves himself), in teacher's opinion concerning child's adaptational difficulties during lessons, and in parents' perspective and according to their experience of problems, children were ascribed to the particular character groups.

Four character groups were distinguished, dependent on the field of the problems experienced, which are formed by dominating character features of the child: reticence, responsibility, attention seeking, and dependence.

Incommunicative child. The attitude of the incommunicative child: the main attitude is that nobody can love the child, and while facing critique he/she feels as if being attacked and humiliated; avoids close relations, breakaway from others, hardly talks, tries not to communicate with others and withdraws from them, never approaches first; if someone tries to speak to him/ her, he/she usually does not answer; answers are short, official, cold; he/she is not able to make friends and communicate with other children, to show friendliness to others.

Responsible child. The expressions of responsible behaviour: acts according to the rules, obeys them; behaves carefully, deliberately, faces difficulties when there is a necessity to behave spontaneously; everything is planned, the unplanned behaviour is embarrassing; does not like innovations, changes; feels discomfort if there is no possibility to put things in the right order; is not able to work without rules; hardly adapts to chaotic environments; faces difficulties while setting their rules and prescribe too much; is not able to work in a mess, does not know how to be incoherent, wasteful, in persistent.

Egoistic child. Attention-seeking child's behaviour is demonstrated in the following way: cannot stay in one place for a long time and finish the work thoroughly; loves changes, if there are none, is seeking for them; tries to attract the attention of others by certain behaviour and to be in the focus of attention; avoids following the rules and is distinguished for impatience; acts freely and takes risks; behaves in such a way that it would be good here and now; is distinguished for a lack of patience, does not know how to wait, hardly controls him/herself, is not punctual, cannot plan, be alone, accomplish individual tasks, implement what is planned patiently.

Dependent child. Diffident child's behaviour: hardly parts with parents; during breaks frequently cuddles with the teacher, i.e., seeks for closer contact; reacts to others' opinion; is not able to challenge him/herself; is not able to be aggressive in a healthy way; is distinguished for excessively peaceful, altruistic, and compassionate behaviour; cannot protect him/herself from sneering; does not show initiative without encouragement.

Character features of the balanced child are understood as an ability to control behaviour in new situations and to react adequately to the present situation, as well as to feel an inner harmony. The already mentioned character features are characteristic of the child (reticence, responsibility, seeking for attention and dependence), four main general attitudes and behaviour possibilities, i.e., a child capable of measuring the situation, and reacting to it adequately with one of the character features, without disturbing the inner balance. 


\section{RESULTS}

In order to help younger pupils in overcoming difficulties, children with dominant characteristics were distinguished, which disturbed them to belong to the new, unfamiliar school environment. In the process of observation, children were distinguished and grouped according to the dominant and harmonious character features, as well as adaptational difficulties of behaviour, which are observed in daily activity. The results are presented in the $1^{\text {st }}$ example (see Figure 2).

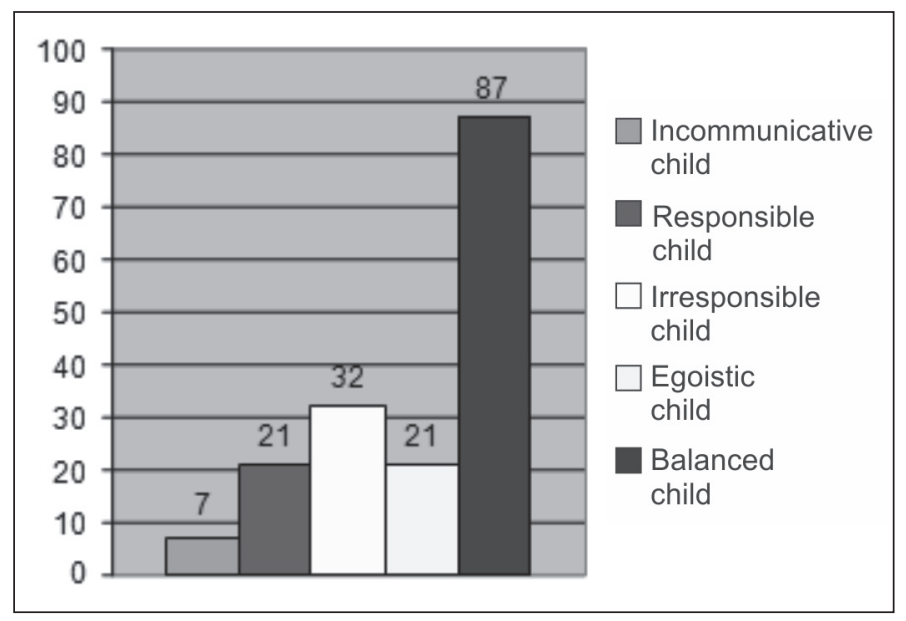

Figure 2. $1^{\text {st }}$ ex.: First-year pupil division according to character type

It can be seen from the example, that 87 children are distinguished for harmonious character features, therefore their behaviour during lessons and breaks did not cause adaptational difficulties. According to the dominating character features of the developing personality, other children were subdivided in such a way: 7 ascribed as incommunicative children, 21 children attention-seeking, 21 children - responsible persons, 32 children - dependent personalities (see Figure 3).

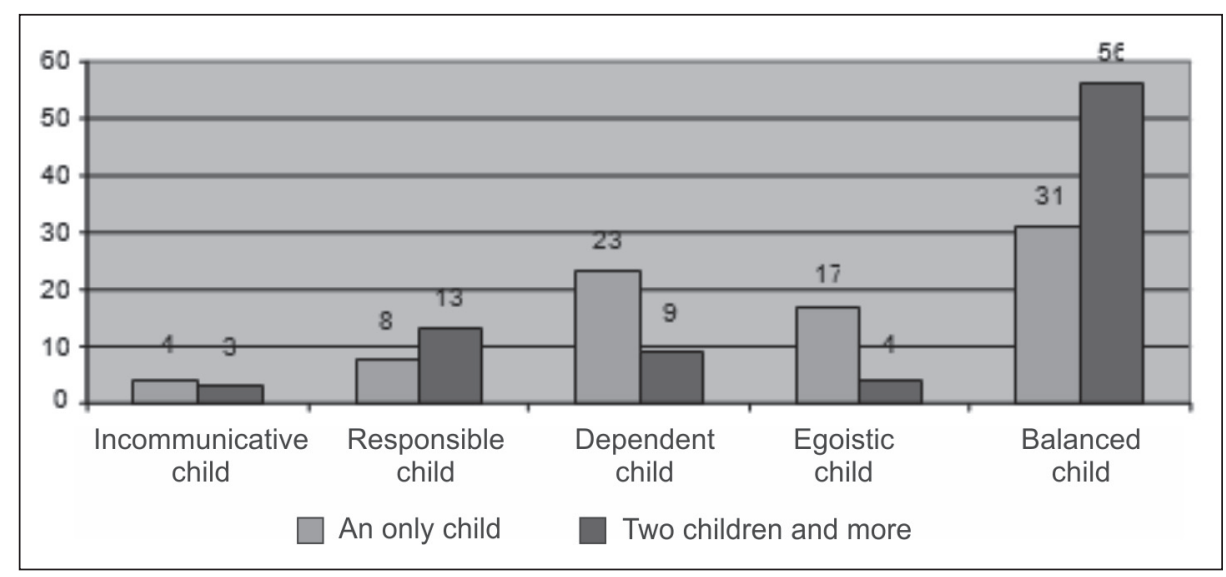

Figure 3. $2^{\text {th }}$ ex.: First-year pupil division according to the dominant types of character and the number of children in the family 
The research showed that among incommunicative children there are 24 only children of the family and 3 children from the families with more than one child. Among responsible children -8 are the only children of the family, and 13 come from families with more than one child. Among dependent children - 23 are the only children of the family, and 9 - from the families with more than one child. Among attention-seeking children - 17 are the only children of the family, and 4 - from the families with more than one child. Among balanced children -31 are the only children of the family, 56 - from the families with more than one child.

Balanced child personality determines the choice of optimal form of behaviour, the formation of adaptive behaviour and it is managing in various action spheres (personal, studying, leisure, etc.). Children who have dominating character features inadequately react to various life situations and new circumstances, which might influence both personal and social adaptation problems.

During the ethnographic investigation data was collected, on the number of children in the family, in order to estimate the proportion of children's personality structure and number of children.

A child, who gets into the new unfamiliar environment, not displaying the character features of the harmonious personality, will experience adaptational difficulties, and will be unable to readjust quickly, reacting to the shifting environment, and changing his/her behaviour, aiming to satisfy his/her needs. The survey of parents and teachers does not reflect the real situation their data cannot be used as the only source in measuring children's behaviour expression of the dominating character features in school, therefore an impartial observer is necessary.

Referring to the results of the observation we revealed expressions of adaptational difficulties of the first-year pupil in daily class environment, moreover, we concluded that it should be corrected. In order to provide a timely correction for children, we regard to empirical investigation and direct work of A. E. Kazdin, T. C. Siegel and D. Bass (1992), in correcting adaptational difficulties of firstyear pupil at school, we refer it to parents and teachers.

Adaptation is the spiritual comfort of a person, not necessarily positive, regarding public's opinion. The human being dominates the world because he/she can quickly adapt to the changing conditions. Therefore, modern parents should quickly react to social changes and crises, by artificially trying to construct the conditions for the development of the harmonious person, in order to prepare for children for independent life, to enable them to adapt to the new environment, to the majority and to handle a new position. The investigation was orientated towards the relations among parents and children, children and teachers, and their influence on children's behaviour. Realising that these interpersonal relations are significant to children's sociability, programmes of parents and teachers' education were implanted: parents and teachers' involvement in discussions, introduction to various features of children's behaviour, etc. Finally, children who participated in the experiment received higher evaluation of the progress, because this is requested in the programme of education.

\section{CONCLUSIONS}

Main reasons and ways to avoid the adaptational difficulties of the first-year pupil:

1. Though 60 percent of possibilities of preparation for life are realised until the beginning of the first grade, the analysis of various authors' research, the quantitative analysis and observation of first-year pupils' in the schools of Vilnius enabled us to make a conclusion that the main reason for difficult adaptation of first-year pupils is the prevailing attitude, that human preparation for life begins at school. 
2. Children's upbringing both in the family and at school is based on a wrong attitude. Educational system is based on the rendering of knowledge rather than on the development of ability to think and universal recognition of the environment.

3. Unactivated brain during infancy and early childhood reduces the possibility to master information provided at school, and use them in life. The process of dehumanization starts in limiting infant's freedom of movement and experiences of natural phenomena, as well as laws that regulate these phenomena.

4. Family is the basis, providing the feeling of safety, which instils real values, which construct conditions for the development of resistance to social changes, and various adaptational skills, which are particularly necessary in the contemporary changing society. Therefore, more attention should be paid to strengthening family values in society and the problems of youth in Lithuania. Extra attention should be paid to the education of parents and their preparation for responsible parenthood.

\section{REFERENCES}

Baumrind, D. (1971). Current patterns of parental authority. Developmental Psychology, 4(1, Pt. 2), 1-103.

Bowlby, J. (1969). Attachment. New York: Basic Books.

Burvyte, S. (2011). First grade students in the adaptation school educational adjustment: PhD thesis. Vilnius: Vilnius Pedagogical University. 301.

Burvyte, S. (2011). Realisation of potential personal adaptation in childhood. European Integration and the Baltic Sea Region: Perspectives and Diversity. Latvia: The University of Latvia Press, 605-620.

Burvytè, S. (2004). Adaptacija ir jos raiška pradineje mokykloj [Adaptation and its expression at primary school]. In Pedagogika, 73, 83-88.

Eisenberg, A. (1999). Pirmieji kūdikio metai [First year of an infant]. Kaunas: Tyrai.

Erikson, E. H. (1968). Vaikystè ir visuomene [Childhood and society]. Reprinted/translated in 2004. Vilnius: Katalikų pasaulio leidiniai.

Gliokler, M. (2003). Tarpusavio santykiu galia [The power of intercommunications]. Vilnius: Lietuvos Valdorfo pedagogikos centro leidybos grupè.

Grigas, R. (1995). Tautos likimas [Nation's Destiny]. Vilnius: Rosma.

Helbrüge, T., \& fon Wimpfen, J.H. (1998). Pirmosios 365 dienos: kūdikio vystymasis [The first 365 days: Child's development]. Vilnius: Avicena.

Horney, K. (2004). Neurotiška mūsu laiku asmenybė [Neurotic personality of today]. Vilnius: Apostrofa.

Kardelis, K. (1997). Moksliniu tyrimu metodologija ir metodai [Scientific research methodology and methods]. Kaunas: Technologija.

Kazdin, A. E., Siegel C. T., \& Bass, D. (1992). Cognitive problem-solving skills training and parent management training in the treatment of antisocial behavior in children. Journal of Consulting and Clinical Psychology, 60 (5), 733-747. Retrieved March 16, 2011, from http://webs.wofford.edu/.

Kvieskienè, G. (2005). Pozityvioji socializacija [Positive socialisation]. Vilnius: Publishing Office of Vilnius Pedagogical University.

Маслоу, А. (1999). Новые рубежы человечиской природы [The new borders of human's nature]. Москва: Смысл. 
May, R. (2010). Meile ir valia [Love and will]. Vilnius: Vaga.

Miškinis, K. (2003). Šeima žmogaus gyvenime [Family in human’s life]. Kaunas: Aušra.

Pfiffner, L. J. (2001). Father absence and familial antisocial characteristics. Journal of Abnormal Child Psychology, 29(5), 357-367.

Piaget, J. (1954). Intelligence and affectivity. Palo Alto, CA: Annual Reviews.

Riemann, F. (2004). Pagrindinès baimès formos [Basic fear forms]. Vilnius: Alma littera.

Выготский, Л. С. (2005). Психология развития человека [Human‘s development psychology]. Москва: Издво Смысл; Эксмо.

Dr. Sigita Burvytė (PhD) - Doctor of Social Sciences (Education)

Lecturer at Lithuanian University of Education Social Communication Institute Social Education Department Address: Studentu str. 39, LT-08106 Vilnius, Lithuania

E-mail: sigita.burvyte@gmail.com 